\title{
Three Decades of Agricultural Extension in Mozambique: Between Advances and Setbacks
}

\author{
Mateus João Marassiro \\ Doctoral student at Federal University of Viçosa, Department of Rural Economics, Lecture at \\ Lurio University. E-mail:marassiro@yahoo.com.br
}

Marcelo Leles Romarco de Oliveira

Lecture at Federal University of Viçosa, PhD, Department of Rural Economics. E-mail: marcelo.romarco@ufv.br

Sergio Feliciano Come

Lecture at Zambeze University, PhD. E-mail:sergiofcome@gmail.com

Received: Dec. 19, 2019

Accepted: Mar. 9, 2020

Published: Mar. 10, 2020

doi:10.5296/jas.v8i2.16647

URL: https://doi.org/10.5296/jas.v8i2.16647

\begin{abstract}
This article aims to analyze the intervention in the area of public agrarian extension in Mozambique, taking into consideration the trajectory of this policy in this country. The methodology used is the literature review and consultation of documents that guide the agrarian extension in the country. Documentary analysis of plans and programs that address the theme was performed, as well as the consultation of articles available on Google scholar published between 2000 and 2019, which brought discussions about agrarian extension. The results suggest that the intervention of extension technicians is still low. This reality may be associated with the fragility of agricultural extension sector policies and agricultural policies that support the area. The verified data demonstrate that the number of extensionists tends to increase, but the rate of farmers who benefit from these services tends to reduce. Low coverage of extension services and poor consideration of farmers' social economic conditions at ultimately contribute to low rates of agricultural productivity. Therefore, agrarian extension services should be taken as a fundamental support instrument for farmers, contributing to the increase of agricultural production and productivity and to the improvement of economic social and commercial conditions in Mozambican agriculture. Therefore, it is considered relevant for Mozambique to develop land extension policies and implement them to enable greater capillarity with farmers.
\end{abstract}


Keyword: extension, agriculture, production techniques

\section{Introduction}

Extension action is inherent to the human presence, involving the exchange of knowledge and techniques between farmers and extensionists. Such exchanges can help farmers to improve their living conditions. Therefore, extension action can have good results if farmers' knowledge is contemplated by the extensionists assuming extension as a process of knowledge exchange between them, in a dialogical perspective (Freire, 1983). The modernization of techniques for promoting development must be anticipated by communicating what needs to be changed and why it is important to promote such change.

Veraszto et al., (2009) state that technology is conceived in function of new demands and social demands and ends up modifying the whole set of customs and values and, finally, the culture is added. Although part of the artifacts and products that surround us, technology is the knowledge behind this artifact, not just the result and the product, but the conception and the creation.

Although the extension action aims, among several actions, to present to the farmer the technology and its effects on agricultural production and productivity, Fang and Richards (2018) report that small numbers of farmers adopt appropriate techniques by other farmers, but most become simply observers even if implemented by neighboring farmers. This reality of the difficulty of transmitting knowledge and the arrival of technology associated with new ways of producing contemporary agriculture is a fact in Mozambican agriculture. In this regard, the Mozambican government has been carrying out agricultural extension service reforms to improve its contribution to farmers' lives.

Novunga (2006) argues that to increase the coverage rate of agrarian extension services in Mozambique, outsourced civil society and the private sector become part of the extension. As a mechanism for strengthening this service, agricultural research pays an important role, so in 2004 the Institute of Agricultural Research of Mozambique IIAM (Portuguese acronym) was created, replacing the National Institute of Agricultural Research INIA (Portuguese acronym), aiming to obtain better scientific and technological agrarian results in different agro-ecological zones. Cunguara and Thompson (2018) argue that IIAM (Portuguese acronym) employs most agricultural researchers and focuses on crops livestock, forestry and natural resources. This research institution releases agricultural technologies after their adaptation in partnership with the extension services. In some cases, IIAM (Portuguese acronym) releases technologies directly to farmers.

The other crucial reform to enable decision-making and support for farmers' use of technology is the access to credit, especially seasonal credit, which enables the acquisition of agricultural inputs (seed, fertilizers, pesticides and agricultural machinery). These inputs can contribute to the increase of agricultural production and productivity (Adenle et al., 2019; Carrilho et al., 2003). Financed production through development systems is important to ensure effective and profitable participation of farmers in crops for both self-consumption and the marketing of their surpluses (Carrilho et al., 2003). 
Despite the government efforts, the Strategic Agrarian Development Plan PEDSA (Portuguese acronym), point out that the yields of major crops in the family farming sector are very low. For example, the average yields of maize is 1 ton/ha against the estimated potential of 4.5-6 ton/ha (MINAG, 2011), (Portuguese acronym). Ministry of Agriculture and Food Security -MASA (2015), (Portuguese acronym), points out that despite the introduction of programs aimed at increasing production and productivity, the low use of agricultural technologies by farmers contributes to low levels of production and productivity. The same source also mentions that despite low incomes Mozambican agriculture is practiced by over $70 \%$ of the Mozambican population on small farms ${ }^{1}$ contributing $24 \%$ of Gross Domestic Product PIB (Portuguese acronym).

It should also be noted that in Mozambique, the focus of land extension in recent decades has been mainly on promoting food security, reducing farmers' poverty and sustainable economic development (MASA, 2015), (Portuguese acronym). However, investments in the agrarian sector in general and in particular in the agrarian extension have been insufficient to meet the needs and challenges encountered in agriculture. To mitigate this scenario, Szonyi and Blum (2018) recommend that investment for the agrarian sector in developing countries should be at least $1 \%$ of the agrarian gross domestic product. But many countries including Mozambique cannot allocate this investment to the agrarian sector.

One of the sector's biggest concerns is making the farmers self- sufficient by providing that in addition to food security, farmers can sell part of their products to meet the rest of their needs. For Adenle et al., (2019); Cunguara et al., (2013) motivating farmers to produce more is needed beyond the coverage of extension technicians to have infrastructures such as roads, storage systems, input sources and efficient market system on the basis of effective policy implementation of the sector.

Most farmers in sub-Saharan Africa ASS (Portuguese acronym) do not adopt technologies, so their production and productivity tend to remain stationary. There is much criticism of agrarian extension failures in Sub-Saharan Africa. The literature reports extension gaps ranging from inadequate extensionist training, top-down approaches to marginalization of resource-constrained women and farmers (Mutimba, 2014). Mozambique being one of the Sub Saharan African countries still has much to learn from the global experiences of the last

Forty years. For developing countries, the association of top down approach and untrained extensionists limits the possibility of assistance from the disadvantaged farmers and there is a tendency to neglect smallholder problems and concerns affecting agricultural production (Gêmo and Davis, 2015; Baloch and Thapa, 2019). The Mozambican extension has gone through three decades facing monstrous difficulties.

In this sense, the objective of this work is to bring elements that contribute to analysis of the intervention process of the Mozambican Public agrarian extension sector, identifying their action, challenges and perspectives. To this end, as an analytical framework, the policies

${ }^{1}$ representing about $99 \%$ of the total explorations 
promoted from the creation of the Mozambican agrarian extension services in 1987 to 2019 were verified. The articles are expected to illustrate the positive and negative experiences of the three decades of agrarian extension, on the other hand, which can help share future Mozambican agrarian extension policies.

The methodology used was a literature review of themes that address the agrarian extension. Documentary analysis of plans and programs that address the theme was performed, as well as the consultation of articles available on Google scholar published between 2000 and 2019, which discuss about the agrarian extension.

\section{Agricultural Extension Path in Mozambique}

The Mozambican agrarian extension was created in March 1987, thus 12 years after national independence (1975) (Gêmo et al., 2005). Gêmo (2009) states that before the creation of the agrarian extension, the secretary of state promoted cashew and cotton crops. Donor-funded integrated development projects provided technical assistance and facilitated access to agricultural inputs for small farmers. Gêmo (2009); Mosca, (2017) argue that in the period of 1976 and 1982 financial resources, mechanical equipment, improved agricultural inputs and technical personnel were allocated to State Agricultural Enterprises EAE (Portuguese acronym). These companies took the first actions related to agrarian extension. In 1979, the People's Assembly of the Republic ventured the EAE (Portuguese acronym), to assume the role of diffusion centers of agricultural techniques to the surrounding farmers. From 1980, the State induced the creation of a sector that would coordinate the agrarian extension activities. However, because of the civil war that began a year after National Independence, which ended in 1992, with the signing of the first General Peace Agreement, extension services were created in 1987 and were operated with various restrictions. Gêmo et al., (2005) mention that the Mozambican agricultural extension service is one of the newest in Africa. However, public agrarian extension in Mozambique has gone through five distinct phases (Gêmo, 2009) which can be observed in the below summarized Table 1.

Table 1. Phases of Mozambican agrarian extension

\begin{tabular}{lll}
\hline Year & Period & Characteristics \\
\hline $1987-1992$ & Period of establishment & $\begin{array}{l}\text { Oriented to assist farmers organized in } \\
\text { associations, cooperatives. }\end{array}$ \\
\hline $1993-1998$ & Expansion Period & $\begin{array}{l}\text { The extension service is expanded to 86 districts. } \\
\text { Strengthen partnership between NGOs and } \\
\text { international partners. }\end{array}$ \\
\hline
\end{tabular}

1999-2004 Unified Extension System Improve cost effectiveness relationship. Improve (SUE) stage in the context of the connection between extension and search. National Agrarian Quality social and personal inclusion at different Development Program levels. Integration of extension technicians. 

2005-2006 Transition period and local The extension seeks to be guided by guiding changes in public extension documents, journals and the national scale. distribution.
Coverage increases from 86 to 116 districts of the 128 existing districts in the country.

More generalist approach of extensionist.

2007-2016 Creation of the national Decentralization, participatory planning and Agricultural Extension value chain development. Comprising program (PRONEA). agricultural production, livestock and natural National Agricultural resource management. The extensionist now Extension System (SISNE). provides all services and promotes partnership between public and private services.

Source: Cunguara and Thompson, 2018; Gêmo, (2009); MINAG, (2007)

The periods described in the table show that there has always been a need to promote some changes in the functioning of the agrarian extension in order to improve the quality of services provided (Muniz et al., 2018). During the agrarian extension path, not everything was aligned to ensure that the sector was successful. One of the supporting elements for this statement is the number of extension technicians versus the number of farmers needing technical assistance. Therefore, authors such as Gêmo (2009); Cunguara and Thompson (2018) point out that in the period from 2002 to 2015 the maximum rate of assistance of family farmers was $14.8 \%$ in 2005 . The establishment phase (1987-1992) the operation of the agrarian extension was influenced by the civil war.

The expansion phase (1993-1998) occurred after the armed conflict; the peaceful environment favored the expansion of agrarian and rural development initiatives. Family farmers had access to up to $75 \%$ free or subsidized improved farm utensils and seeds. The World Bank supported financially the extension to expand in the provinces of Cabo Delgado, Nampula, Gaza and Inhambane. At central level, funding was provided for the opening of 22 district extension networks, acquisition of vehicles, motorcycles, extension equipment and some inputs for the demonstration Gêmo (2009). In this phase, extension actions were mainly characterized by the distribution of improved seeds, fertilizers and other inputs by both public and private extension. Farmers' social and economic issues regarding sustainability and resilience were not considered because the model was focused on the modernization of family using the top down approach.

The Master Plan (1999-2004) previewed the adoption of a system of multiple provisions of agricultural extension services. This plan formally recognized the pluralistic provision of extension services in 1998, when the Master Plan 1999-2004 was approved. It was also envisaged that such pluralistic provision of extension services would result in a better cost-effectiveness and increase response to farmers compared when public extension was the only one that existed. Muniz et al., (2018) report that the anticipation of multiple actors in the provision of agrarian extension services in Mozambique occurs in an institutional form, but 
not in an intervening and articulated manner, showing only interventions by service offerings and not by demands. This situation is due to the complexity of the agrarian systems and the various dimensions that affect the development of the agrarian sector. Mozambican farmers use logic of production related to the rationality of the producer that is mostly influenced by ecological, social and economic conditions and to some extent limit their production possibilities.

The first Master Plan emphasized the need for a unified rural extension system of the Ministry of Agriculture integrating land and forest service technicians. In the period of 1999-2004, extension worked with an average annual deficit of 173 extensionists, causing the lack of extension services to farmers. The challenges of extension services extended to field logistics and coordination. Apart from the lack of technicians, their level of education also matters. In the 2000s, the public extension had only 48 senior technicians, mostly graduated in agronomy (Gêmo and Riveira, 2001). The collaboration between extension, livestock and forest increased in 2011 and the concern about erosion, post-harvest issues and grain processing was developed benefiting 66 districts Gêmo (2009).

In the transitional phase and local changes in the distribution of public extension, the extension was guided by the Master Plan 1999-2004, which lasted until 2006. Between 2005 and 2006 several districts had between 2 and 5 technicians. At that time, DNEA previewed that each district should have at least 8 technicians. The extensionists were positioned in regions of high and medium agrarian potential, so this situation raised questions at the local level Gêmo (2009). Farmers in the least productive and resource-poor regions continue to be marginalized by extension services.

The Master Plan 2007-2016 intended to promote farmers by transforming them from self-reliant farmers to market-oriented farmers. In their analysis Muniz et al., (2018) proposed the need to revise the unified system to ensure the achievement of the objectives proposed in the Master Plan. Cunguara and Thompson, (2018), in turn, state that the SUE and SISNE program were not successful. The authors point to the lack of incentives for cooperation between extension service providers, so that the government, the private sector and NGOs did not work together. The following section describes the techniques made available by extension services to family farmers and describes how these technologies have impacted farmers' lives.

\section{Techniques Provided by Extensionists and Their Effects}

The agricultural extension sector has made many techniques available to farmers to increase agricultural production and productivity. The Mubai study (2014) conducted in Boane District found that local agricultural extension agents provided chemical and organic fertilization, irrigation and greenhouse use techniques. The study reveals that the technique of using chemical fertilizers was adopted by $9 \%$ of farmers and irrigation by $19 \%$. These techniques resulted in increase of production to $18 \%$ of study participants. The study of Kondylis and Mueller (2014) conducted in Zambézia province in the period of 2010-2012, shows that mulching, crop rotation, no-tillage, contouring, row showing, fallow and intercropping techniques were available. The study of Cunguara and Darnhofer (2011) reveals that the use of the tractor by farmers resulted in a 5\% increase in farmers' income, but the use of other 
technologies did not influence farmers' income. Therefore, technologies had significant impacts on farmers' incomes.

These results may have been influenced by the widespread drought in the 2004-2005 cropping season, the 2005 harvest being the lowest in the last 14 years.

Adenle et al., (2019); Cadena-Iñiguez et al.,(2018) state that in this relationship with agricultural extension services, the farmer needs to see benefits in deciding to accept the practices or the innovations presented by extensionists. In this context, when presenting the techniques to the farmer, it is necessary to fill in the gaps between research and the needs of rural communities to complement them. It can be understood that the farmers' analysis goes beyond technology, as they also see its economic gains. Therefore, in addition to the production process, it is important to have a guaranteed market to absorb the surplus obtained by the farmer (Cunguara et al., (2013); Knickel et al., (2018)). Alves et al., (2016) argue that the challenge of agricultural extension services is to recognize that technology is easily appropriated by farmers if it has social and economic benefits for farmers, while respecting the sociocultural reality of these farmers.

Among the $13.5 \%$ farmers who had access to extension services in 2003 and appropriated the technologies increased their productivity by $8.4 \%$. One of the biggest actions taken by extension in Mozambique is the introduction of new seed varieties, chemical and natural pesticides, soil conservation and crop intercropping (World Bank, 2006). The rate of technology-adopting farmers is very low. Knickel et al., (2018) point out that, farmers think about the costs and benefits of technology before making decision. The technologies are mostly industrial based and most Mozambican farmers have weak economic power to individually purchase inputs. Therefore, the weak purchasing power associated with the disintegration of family farmers in the input and agricultural market may be influencing the adoption of these technologies. On the other hand, Knickel et al., (2018) report that farmers' involvement in technology production considering social, economic and ecological conditions allows most farmers to take ownership of them. This reflection on the need for technology co-production with farmers requires the involvement of social scientists in rural extension.

The extensionist training area influences on the technique to be provided. Mutimba (2014) states that extension technicians from most African countries are composed of agronomy engineers, foresters or veterinarians, making them more attached to techniques while ignoring sociological and cultural issues and farmers are not involved in the extension action planning process limiting themselves to top down planning.

According to Monteiro (2017) the top down model of public policies has been criticized for being characterized by the limited and controlled discretion of the bureaucrat and on the other hand by its organizational bias. Therefore, there is little flexibility in policy implementation. Participatory planning and strong research-extension linkages allow for greater adaptation of techniques to farmers' agro-ecological system and circumstantial resources.

According to Asfaw et al., (2012) agricultural research and technology improvement is crucial for increasing agricultural productivity while reducing poverty. The author further argues that 
the link between research and extension generates technologies that are more adapted to agro-climatic conditions and can guarantee greater production and productivity. Anderson and Feder (2003) argue that the use of technologies provided by extension services help to reduce the differences between potential income and income obtained by farmers.

The 2007-2016 Strategic Plan refers to the extension link with the Institute of Agricultural Research of Mozambique IIAM (Portuguese acronym), but this link is not robust. The investigator tends not to collaborate with the extension technician. On the other hand, the Agrarian Extension Strategic Plan makes no reference to the extension link with higher education institutions. Adenle et al., (2019) argue that public-private partnership is a key to improving farmers' access to technologies and connecting them to markets.

\section{Approaches Used in Agrarian Extension}

For Kondylis and Mueller (2014); Anderson and Feder (2003) the Training and Visit (T\&V) model has been rapidly disseminated by the World Bank since 1975, firstly in South and East Asia and later in Africa. This approach was developed to increase the quality and coverage of extension services. It was intended to expand to reach more women and isolated farmers.

However, Ban and Hawkins (1996) argue that the T\&V model was not successful in Africa as it required farmers to be assisted by well-trained extension technicians and in permanent link with a agrarian research. The authors also report that in this continent an extension worker assisted around 800 farmers. Therefore, for this group of farmers it was recommended to select 80 who would serve as contact farmers. In turn, the extension worker should visit each of the contact farmers once in every two weeks on a fixed week day. Preferably, the visit should be made in the fields of agricultural production for other farmers to participate in debates and demonstrations of best practices. In turn, every two weeks the extension worker benefited from a day of training with experts in agrarian extension matters. The model was unsuccessful for top-down character and overlapping activities.

In Mozambique the T\&V approach was introduced in 1987 and extended until 2006. In this approach, each extension worker assisted between 200 and 250 farmers (Cunguara and Thompson, 2018; MINAG (Portuguese acronym), 2007). During working sections with farmers, the extension worker provided technical information to farmers, and later visited the farmer of contact ${ }^{2}$ (Aker, 2011). The T\&V approach was modified in 1993 to be in line with farmers' economic, cultural and knowledge level, to involve farmers as active participants in their development and to take farmers' priorities as a starting point. The government adopted this approach with financial assistance of the International Fund for Agrarian Development FIDA (Portuguese acronym), World Bank and FAO (Portuguese acronym) (Gêmo et al., 2005).

However, the $\mathrm{T} \& \mathrm{~V}$ model had limitations in its implementation in the country, the first being that the extension agent does not reach farmers from isolated communities because of time and other resources. The second limitation was that the extension agent provided little information

\footnotetext{
${ }^{2}$ The farmer of contact received the train of the extensionist and he trained the other farmers
} 
or was not part of the farmers' demands. Third, the information might not reach other farmers in the community, especially women.

It was also found that the contact farmer did not reach other farmers, perhaps because the

Information was irrelevant or of very incipient quality (Kondylis and Mueller, 2014).

Mozambique was not the only country that adopted the T\&V approach. Anderson and Feder (2003), reveal that this model was adopted by more than 70 countries from 1975 to 1995 . The similarity of Mozambique to the approach failed, because it was demanding on resources that these countries could not cover, among this factors it is possible to highlight: lack of experts in each country, exclusive dedication to agricultural extension, non-compliance with biweekly contact with farmers (possibly insufficient number of technicians), lack of mandatory be-weekly training, and low pay, as well as low logistical support.

Due to insufficient budget for agriculture, poor coverage and low training of technicians, Mozambicans were unable to maintain the T\&V approach. Between 2003 and 2004, the school approach was introduced experimentally in the Farmer Fields School (FFS). The methodological change in the availability of extension techniques constituted a reform. Nuvunga (2006) states that the Mozambican agrarian extension, from 1999 onwards, became a unified extension system, according to which the extensionist began to provide technological messages from different areas that afflicted the farmers. The 2004-2009 Extension Master Plan marks a turning point from the T\&V system to the FFS methodology; the aim was to enable farmers to participate more in knowledge exchange. The FFS approach was introduced in the Philippines and Indonesia in the 1980s for integrated pest management and has been expanded and introduced in 78 countries. The approach is based on participatory methodology in terms of farmer focus, experimentation and problem solving. Anderson and Feder (2003); Innocent and Vasanthakaalam (2018) report that after Asia the FFS approach was introduced in SSA countries in the mid-1990s and was established in at least 27 countries. In Mozambique, this approach is now being used by the public extension network as well as by NGOs (Cunguara, and Thompson, 2018; MINAG (Portuguese acronym), 2007). Dzeco et al., (2010) argue that the approach was initially implemented in Zambézia province in 2003 in 124 schools involving 400 gardeners. In 2004, the experience was expanded to the provinces of Maputo, Manica and Sofala. This model also utilizes contact farmer, with participatory training methods that build farmer capacities (Aker, 2011). The most recent Agricultural Extension Master Plan PDEA (Portuguese acronym), (2007-2016) highlights the use of the modified T\&V approach based on the principles of interactive learning and farmer needs and proposed multiple service providers (MINAG, 2007), (Portuguese acronym). From 2011 onwards the extension began to implement a participatory approach, this model takes into account farmers' conditions and different National and regional circumstances within and between provinces. The Master Plan envisaged assisting farmers individually and in groups taking into account their specific circumstances, needs and farming system.

Muniz et al., (2018) consider that the implementation of the PDEA (Portuguese acronym), reveals certain vulnerability, as the technicians responsible for its operation at provincial and district level continued to have the same training, and it's therefore necessary that these 
technicians be trained. The provisional services in isolation did not consider the lack of proportionality between the number of extensionists and farmers who demand these services. The authors consider that there was no coherence between the proposed PDEA (Portuguese acronym) and the executed. One of the mechanisms to minimize policy failures and inconsistencies is to promote the participation of different actors in planning. It helps to democratize the relationship between individuals. It allows a greater interaction of technicians and farmers in the construction of new knowledge more compatible with the economic and social life of the farmers involved. This new view supposes the breaking of the hierarchy of knowledge and the recognition of farmers' tacit knowledge, for the construction of more complex knowledge, mediated by reality (Caporal, 2005).

From the analyses made to the Master Plan 2007-2016 it was noticed that although there is a tendency to use participatory approaches, the term diffusion of technologies is still there. Therefore, the Mozambican agrarian extension still has classic diffusionist spirit of Everett Roger, who became known as the Rogerian paradigm or theory of diffusion of innovations. Rogers' diffusionism has little consideration for issues related to the technical, economic, social, cultural and political aspects of assisted communities.

Muniz et al., (2018), point out that in 2010, the Ministry of Agriculture established the Integrated Technology Transfer Program PITTA, (Portuguese acronym), with the aims of adapting innovations for later transfer to farmers. Therefore, the model is empirically operationalized from the extensionist, who received an area of one hectare, called a model area, producing directly by the use of technological packages improved by the investigation. The resources used in the model area for the acquisition of technology packages came from the Ministry of Agriculture's Agrarian Development Fund FDA (Portuguese acronym). Cunguara and Thompson (2018) reported that it was not clear whether this resources where donation or credit. Therefore, many extensionists were unable to carry out the activities because the inputs and other support previewed by PITTA (Portuguese acronym) did not reach them, making this project one of the most criticized.

Taking in a broader look Davis et al., (2010) point out that in the African context, land extension faces a number of challenges and it is difficult to find a more appropriate extension approach for African countries, as poverty is raising and productivity is shrinking in the continent. Muniz et al., (2018) highlight that production and productivity are influenced by multiple variables, such as physical, social and economic. In this study Davis (2008) notes that the failure of many of these extension models to achieve their objectives effectively, along with limited budgets to support public extension, has led to reforms in most SSA countries. In this context, the author states that reforms ${ }^{3}$ are not changing the system used as much as the approaches within the system.

\footnotetext{
${ }^{3}$ Including the use of providers and plural extension approaches decentralization, privatization contracting entry and exit costs demands oriented approaches and participatory, rates of services and use of information and technological information.
} 


\section{Main Limitations on Agrarian Extension Activity}

MINAG (Portuguese acronym), (2007) reveals that agrarian extension in Mozambique faces several limitations to reach farmers, and these include: (i) the great social economic, ecological and diversity of cropping systems combined with a relatively low population intensity; (ii) the complexity of cropping systems and the lack of cost-effective new technologies; (iii) low effective demand for extension due, among others, to farmers' level of education, insufficient financial and human resources, and poor market orientation. The challenges that the Ministry of Agriculture points out significantly influence extension services, the case of low population density is indicated by Szonyi and Blum (2018) as a factor limiting the possibility of farmers being assisted by extension workers as it requires technicians to have cars and fuel beyond the time needed to reach farmers, the situation becomes more complicated when roads are precarious.

Another problem with extension services is limited coverage and the provision of low quality services. Table 2 below shows the influence of the limitations that affect the agrarian extension in the period from 1997 to 2015.

Table 2. Influence of limitations affecting agrarian extension

\begin{tabular}{lllll}
\hline Year & $\begin{array}{l}\text { Received } \\
\text { extension }\end{array}$ & Access to credit & $\begin{array}{l}\text { Received } \\
\text { information } \\
\text { about price }\end{array}$ & $\begin{array}{l}\text { Uses chemical } \\
\text { fertilizers }\end{array}$ \\
\hline 1997 & 13 & - & - & - \\
2002 & 13,5 & - & 34,5 & 3,7 \\
2003 & 13,5 & 2,9 & 47,2 & 2,5 \\
2005 & 14,8 & 3,5 & 40,3 & 3,8 \\
2006 & 12 & 2,9 & 36,3 & 4,6 \\
2007 & 10,2 & 4,7 & 33,1 & 3,6 \\
2008 & 8,3 & 2,6 & 34,2 & 2,8 \\
2012 & 6,6 & 2 & 49 & 5,6 \\
2013 & 8,9 & 1,7 & 43,3 & 4,6 \\
2014 & 8,3 & 1,1 & 48,4 & - \\
2015 & 4,3 & 0,4 & 13,6 & 3,6 \\
\hline
\end{tabular}

Source: Cunguara and Thompson, 2018; Guanziroli, 2015; MASA, 2015, 2014; Mabiso et al., 2014; Gêmo et al., 2013; Gêmo, 2009; MINAG, 2007 


\section{Macrothink}

Table 2 shows that 2007 about $13 \%$ of farmers had access to extension services. This percentage increased to about $15 \%$ in 2005 . From the time on, the number of assisted farmers begun to decrease having reached $4,3 \%$ in 2015 . Regarding to credit access the table shows that in 2003 about $3 \%$ of family farmers had access to credit, in 2007 the rate of beneficiaries increased to about 5\%, the rate decreased to $2 \%$ in 2012 and in 2015 fell to 0,4. This sharp downward trend of credit-seeking farmers' contrasts with the District Development Fund policy (commonly known as 7 million meticais ${ }^{4}$ ) implemented from 2005 . However, the rate of farmers who received information about the price of agrarian products remained about $30 \%$ in the period of 2002 to 2014 and fell to about $14 \%$ in 2015 . The rate of farmers using chemical fertilizers was higher $(5,6 \%)$ in 2013 and was lower $(2,8 \%)$ in 2012.

The access to agrarian extension services refers to physical interaction between farmers and extensionist or the farmer of contact trained by the extension (Gêmo et al., 2013). In the period between 1997 and 2015, the access to these services by family farmers was not satisfactory mainly the coverage rate, which in some way influences the rest of services offered by it.

The data show a failure of 2007-2016 PDEA's (Portuguese acronym), propositions to increase coverage and beneficiaries of the extension, because during its implementation the rate of assisted farmers was decreasing year to year. This situation may be related to the disarticulation of the extension policy between the actual propositions and real capabilities of its implementation. Gêmo et al., (2013) point out that in the period between 2006 and 2008 the extension was expanded to new districts but there was no increase in other workers in public services, this situation may have influenced for some extension technicians to hold positions of leadership, reducing the chance of these technicians of exercising extensionist activity.

The relatively low rate of farmers who have started using chemical fertilizers may not only be related to access to extension services, but also the social, economic issues of farmers on one hand, on the other hand the market issue and infrastructure may be having a very strong effect on decision making of the use of fertilizers. Knickel et al., (2018) argue that in a weak integration system of family farmers in to the market, access to credit can become a "cancer" for the farmer and his family.

The Strategic Plan for the Development of the Agrarian Sector PEDSA (Portuguese acronym), does not refer to credit policies for farmers in the family sector. The financing at lower interest rates could stimulate the decision-making process and adopt more adapted techniques that would promote increased production and productivity. Cunguara and Thompson (2018); Adenle et al., (2019) report that credit access policies, can influence farmers to adopt agrarian technologies. However, it was identified that only farmers of industrial crops such as tobacco had access to credit.

One of the factors influencing the functioning of extension service is the number of the extensionists who ensure the availability of technologies and other relevant information for the farmers. The following graph 1 is the evolution of the number of extensionists from 1999 to 2019.

${ }^{4}$ USD 113140,45 exchange rate of 30.09.2019 


\section{MInstitute ${ }^{\text {Mnk }}$}

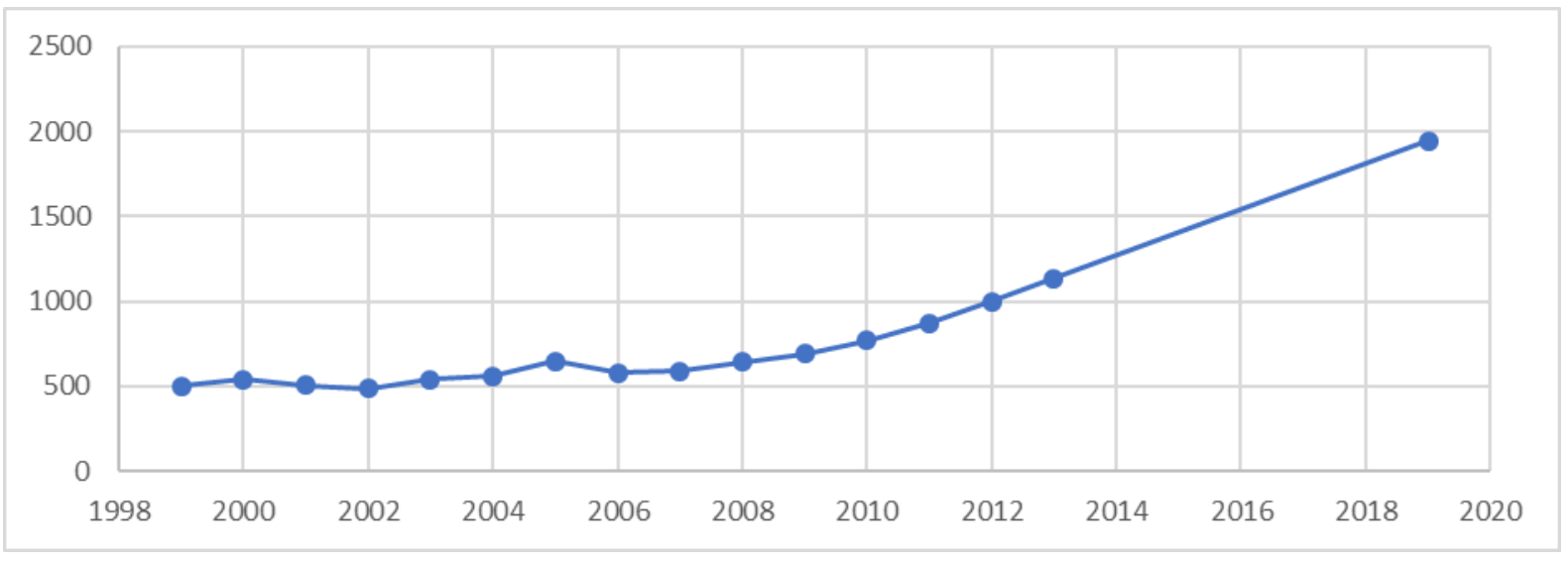

Figure 1. Evolution of the number of extensionists

Source: DNEA, 2019; Gêmo; Davis, 2015; Gêmo et al., 2013

Figure 1 illustrates that in 1999 the extension worked with 501 technicians, this number was growing moderately, because by 2007 the number of extensionists increased by only 89 extension technicians. Even in the implementation period of the PDEA (Portuguese acronym), the evolution of the number of extensionists continued to be moderated. The increase in extension technicians presented in Figure 1 although it is not significant does not justify the significant drop in the rate of farmers in the family sector that had access to these services in the period of 1997 to 2015 of the Table 2. This situation may be related to the limitation of resources issues, disjointed logistics and some extensionists may be engaging in activities which are not of technical assistance to farmers. Despite the recognition of the importance of this service in combating poverty, the Mozambican reality shows that the overall contribution of agrarian extension services to poverty reduction is undesirably low. This service is far from meeting the demand of about $67 \%$ of family farmers. Cunguara and Thompson (2018) point out that the number of extensionists is still far from meeting demand; official statistics show that the coverage rate of public extension is still about $4 \%$ of the total households practicing agriculture in 2015. Working conditions discourage some technicians by influencing the search for better job offers in NGOs. In 2019, the data available in the National Directorate of Agrarian Extension point to a total of 1.947 extensionists until the first half of that year. Despite the considerable increase in the number of extensionists many farmers do not yet have access to agrarian extension services.

Szonyi and Blum (2018), state that the number of extension technicians is determined by multiplying the number of farmers claiming extension services by the number of extensionists. So only then, can one ensure greater coverage and effectiveness of extension services. Assuming that each extensionist assists up to $250 \mathrm{AFs}$, Mozambique would need about 18,000 extensionists to assist about $67 \%$ (18.7 million inhabitants) of the population dedicated to agricultural activity. That is, even with the increase in the number of extensionists, between 2005 and 2019 the country is still far from that number. In this sense, it can be affirmed that Mozambique has a deficit of about 16 thousands of extensionists according to the FAO recommendation. In addition to the numbers and the coverage of 
extension services, the training areas of extensionists themselves are a key factor for the success of these services.

With regard to the training of these agrarian extension technicians, most are agronomy engineers, forestry and veterinarians. Looking at the complexity of farmers' needs as members of society, with a certain culture exploring different agro ecological regions the involvement of nutrition technicians, environmental technicians, anthropologists and sociologists could streamline rural development. However, the lack of budgetary resources, for hiring a transdisciplinary team or even for the training of technicians can limit this possibility even if the sector has the initiative.

The PDEA (Portuguese acronym), planned to increase the number of extensionists at national level to ensure greater coverage and ensure quality of information and technologies to farmers. Figure 2 shows the current distribution of extension technicians by the provinces.

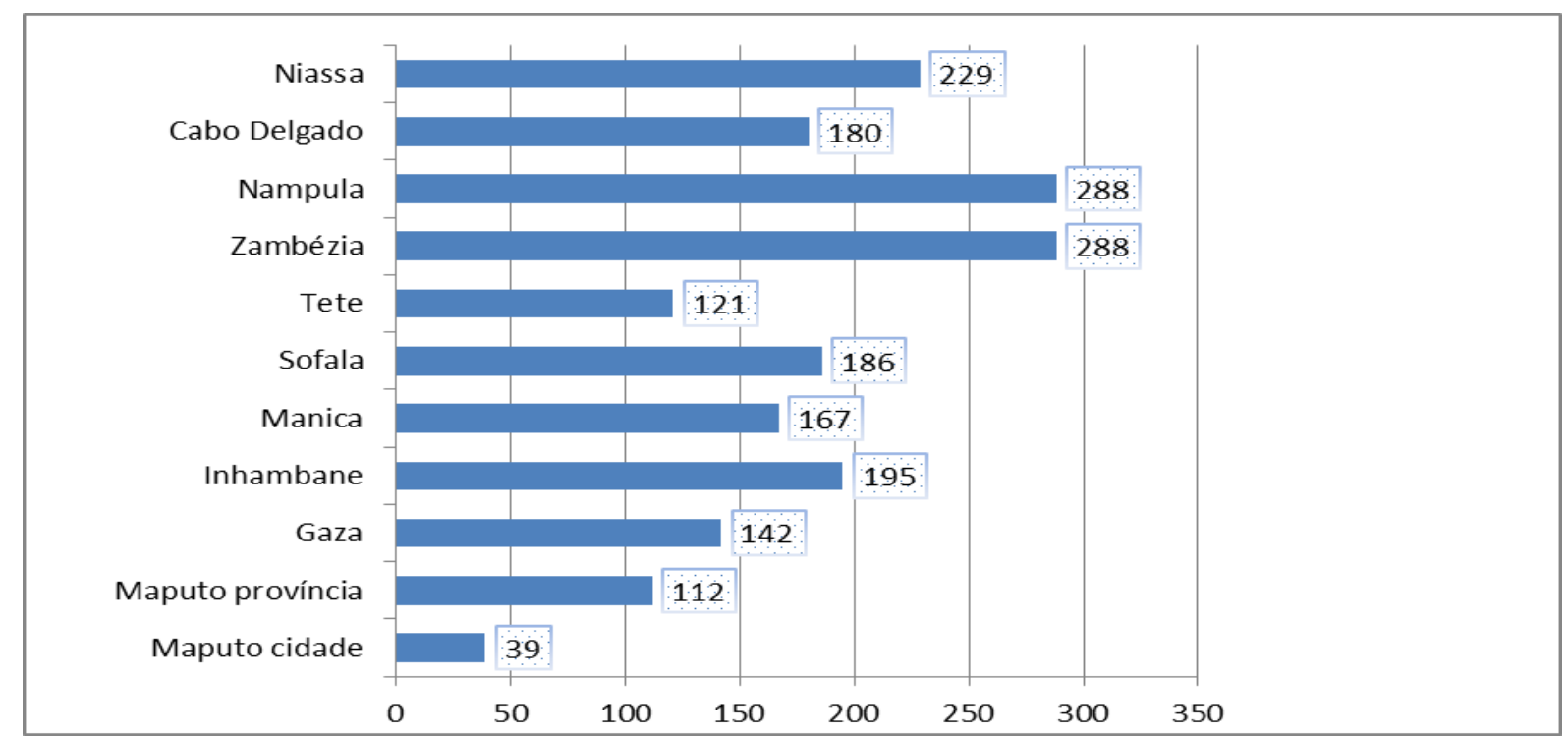

Figure 2. Distribution of extensionists by provinces (in 2019)

Source: DNEA (Portuguese acronym), 2019

As the figure shows, the provinces of Nampula and Zambezia have a higher number of extensionists (288) each. According to INE (Portuguese acronym) (2019), the two provinces are the most populous with 5.8 million and 5.2 million respectively, most AFs practice agricultural activities for self-sustaining and contribute significantly to the country's overall production. On the other hand, Maputo city and province are the ones with the lowest number of extensionists, 39 and 112 respectively. For the case of Maputo city, this can be justified by the small existence of people who practice agriculture. Although the number of extensionists tends to corroborate the number of farmers per province it should be noted that it does not yet satisfactorily cover the needs of AFs dedicated to agricultural activity. On the other hand, the distribution of extensionists does not consider the issue of agricultural potential that the provinces present. Therefore, if the Northern provinces (Cabo Delgado, Nampula and Niassa) and of the Centre (Zambezia, Tete, Manica and Sofala) considered this aspect, they would 
have a greater number of extensionists compared to the other southern provinces of the country. The scenario described requires the Mozambican Government to redouble efforts to minimize the resource gap in the extension sector.

Therefore, in addition to the deficit of extensionists there are studies that reveal other limitations for the execution of agrarian extension activity. Come and Cavane (2014) reveal that one of the problems that extension technicians face is related to transport deficit, mechanical failures and access routes in poor traffic conditions. Sitoe (2010) in his study conducted in Maputo found that agrarian extension services had problems with: (a) insufficient means of transport, (b) insufficiency of technicians, (c) low academic qualification of technicians and (d) limited incentives.

In this sense, Muniz et al., (2018) report that extension services face financial limitation to empower technicians at different levels, as well as to empower farmers. Therefore, the qualification of extension technicians at the central, provincial, and district levels remained constant during the implementation period (2007 to 2010) of the National Agrarian Extension Program PRONEA (Portuguese acronym). For the same authors, this situation remains one of the critical factors in the design and implementation of industry plans and programs. Corroborating this statement we noticed that financial resources limit and impact the training of extension services technicians, i.e. in the period 1999 - 2004 approximately USD 20.44 million was approved, but the amount made available was in about $60 \%$. This cut affected the area of training and services, field demonstrations and monitoring and evaluation supervision (Gêmo and Rivera, 2001).

Even if the study has not obtained budget data throughout the period under analysis, it should be based that the budgets allocated to the extension sector have not been sufficient to meet the demands. One example of this is limited hiring of technicians or investing below recommended. In this case, data from MINAG (Portuguese acronym),(2007) show that annual investment in 2007 was only $0.69 \%$ of the GDP of agriculture, however, FAO recommends that investment for the agrarian sector in developing countries such as Mozambique should be above $1 \%$ of the agrarian GDP. This investment could enable agrarian extension activities and the agrarian sector in general.

On the other hand, the issue of the lack of educational investment has contributed to the perpetuation of illiteracy ${ }^{5}$, being still very high in the Mozambican population, which constitutes an obstacle to the process of making agrarian technologies available and taking decisions. According to the National Institute of Statistics - INE (2019),(Portuguese acronym) the illiteracy ${ }^{6}$ rate is $39 \%$ of the Mozambican population. Moreover, there is the issue of diversity of maternal languages ${ }^{7}$, i.e. some extensionists do not have the mastery of local languages. Therefore, the extensionist uses the farmer who has a minimum notion of the

\footnotetext{
${ }^{5}$ Not have reading, writing and numeracy learning to meet basic needs

${ }^{6}$ INE (2019) consider illiterate citizen with 15 years who doesn't read and write

${ }^{7}$ Mozambique has about 22 mother tongues
} 
Portuguese language. This reality ends up affecting the possibility of using information and communication technologies (ITCs), and it is necessary, therefore, to establish parameters that consider these linguistic particularities in the communities served by the extension services. Adenle et al., (2019) point out that farmers' education influences the communication process between extensionists and farmers in rural areas.

The use TICs (Portuguese acronym), is still very weak although its implementation is almost the age of agrarian extension in Mozambique. Castelo and Braun (2006) points out that the main challenge in rural areas is the access to radio and television, for this reason, it may even be necessary to adapt strategies to the context and local infrastructure. And on the other hand, due to levels of illiteracy the messages should be conveyed in local languages. In the Mozambican context, the most accessible and most used mass media by farmers is radio.

However, they are not always able to listen to programs because sometimes batteries are missing (in rural areas) and on the other hand, agrarian interest programs are transmitted at times that farmers may sometimes be working in their fields. The INE (2019) (Portuguese acronym), points out that $35 \%$ of the Mozambican population have radio, $26.4 \%$ have a cell phone and $6.6 \%$ have internet access. These data show that few Mozambicans have access to ITCs, so the use of these technologies may not help much to cover the deficit of extension technicians that the country lives.

Also on ITCs, in 2015, about 450 hours on community radio were dedicated to agriculture programs, national radio (Radio Mozambique) broadcasted 74 hours and Mozambican television broadcasted in 28.5 hours (Cunguara and Thompson 2018). The information may even be welcomed by the farmer, but because the radio does not allow feedback some farmers may be afraid to make certain decisions.

Gulati et al., (2018) point out that the use of ITCs in India in the process of providing agrarian technologies using mobile phones, internet, television and radio allowed information to reach farmers quickly and lowered the costs of extension services. These data challenge the Mozambican state to invest in ITCs to increase the possibility of reaching more farmers.

In addition to ITCs, infrastructure such as roads and warehouses for the conservation of agrarian products influence costs and their use. Albuquerque and Hobbs, (2016) report that agricultural input prices (Fertilizers, seeds) are quite high in parents especially at district level due to degradation of access routes, making them inaccessible to farmers in the family sector. In the city of Lichinga (at the exchange rate ${ }^{8}$ of 09/30/2019), the $50 \mathrm{~kg}$ bag of NPK fertilizer cost US\$39.6, the $50 \mathrm{~kg}$ bag of Urea cost US\$ 38.8 and the bag of $50 \mathrm{~kg}$ of maize cost US\$ 80 .

The precarious conditions of Mozambican roads, especially in rural areas, make agricultural inputs even more expensive, influencing the availability of these rarer. In some cases, the seed costs 10 times more the price of grain for consumption, a fact that induces the farmer to use the grain from his barn or neighbor's barn, with low quality as seed. Therefore, the

${ }^{8}$ USD $1,00=$ Meticais 61,87 
government should make an effort to improve roads to minimize production costs (Albuquerque and Hobbs, 2016).

Cunguara and Thompson (2018) argue that because of road precariousness and resource restrictions (vehicle and fuel), farmers living near paved roads are most likely to be achieved by extension services. Despite this situation, Cunguara and Moder (2011) state that there was no statistically significant difference between the receptions of extensionists visit of living near the road farmers and those who live far from the road. However, wealthy farmers tend to adopt more technologies than the poor. Kelsey's study (2013) points out those farmers often cite the lack of capital as one of the main reasons for not adopting a technology that could improve their productivity. Adenle et al., (2019) argue that African farmers do not adopt every technology package because of technology costs and market uncertainties.

The storage of agricultural products is still deficient; most farmers lose part of their harvest in the warehouse. The Ministry of Industry and Commerce has built silos in some provincial capitals, but its use is still inefficient and on the other hand does not even cover demand. Cunguara et al., (2013) point out that storage can increase the profitability of the use of improved technologies. Baloch and Thapa (2019) point out that in several developing countries extension services do not improve farmers' technical skills, disseminate technologies more adapted to farmers' conditions, market information and other opportunities, resources have mostly been inadequate, including insufficient budgets, means of transport to cover vast territories and with mostly precarious roads.

\section{Proposals for the Improvement of Extension Services}

After the analyses and discussions of the rout of the Mozambican extension from its creation until 2019 the research leaves some proposals that can contribute to improving the functioning of extension services and providing satisfactory assistance to farmers in the family sector and better the well-being of Mozambican rural families.

The results show that the extension increased the number of technicians, but farmers who benefit these services have fallen and on the other hand production and productivity tend to remain stationary. To reverse this scenario this study proposes whether the hiring of more technicians and other public servants. Strengthen extension teams and create technical training mechanisms to ensure the provision of quality services to farmers and include social scientists in extension teams to search for elements other than in the field of agronomists. The trainings can be done in partnership with existing universities or research institutions in each province or region. There is a need to improve the working conditions of extensionists, ensure incentives and resources to guarantee the efficiency and effectiveness of these services.

Regarding the poor quality of technologies and messages made available to farmers, the research proposes greater collaboration between research institutions, research and agrarian extension services. Strengthen coordination between state institutions and international partners working in agriculture.

As for the resources for the functioning of agrarian extension, the study proposes the 
reduction of external financial dependence for the agrarian sector. $1 \%$ of the agrarian GDP has to be allocated to agricultural sector.

As for the adoption of technologies, the study proposes an increase in farmers' participation in the design of agrarian policies and strategies. Promote farmers' knowledge or experiences in the process of technological innovation and improve the most economically and socially practices, taking into account the ecological conditions of each region or place.

\section{Final Considerations}

The Mozambican agrarian extension is characterized by many challenges ranging from organizational, structural, to the scarcity of financial, material and human resources. Although the Mozambican agrarian extension is very young (1987-2019) this does not justify its poor efficiency.

In the period under review it was found that there were trends of improvement highlighted by the increase in the number of extensionists, but farmers with access to extension services are mostly small farmers whose production and productivity still continues well below potential income. Farmers with credit access also declined. One of the advances highlighted is expansion of extension services throughout the country's districts. While acknowledging that Mozambique has invested in agrarian extension, the number of extensionists has increased, but still has a picture to be improved, as is the case with planning. One example is the fact that the extension is currently operating without an approved Master Plan.

On the other hand, the approaches used tend to be difusionists, although the last Master Plan refers to the participatory approach, which still prevails is the dissemination and transfer of technology disregarding the relationship between technical aspects, economic, social, cultural and political of assisted farmers. Therefore, there is a need to use participatory approaches effectively taking into account the experience, the economic and ecological social issues of farmers, seeking to strengthen farmers and their organizations, through sustainable production systems and providing information and technical assistance compatible with the reality of farmers.

The Mozambican government should make an effort to make at least $1 \%$ of its agrarian GDP available to boost the agrarian sector. The weak budget has been pointed out as being one of the limiting factors for the effectiveness of agrarian extension services. Plans should be adjusted to budgets to ensure their feasibility to guarantee increased production and productivity and generally the social and economic changes of farmers.

It would also be important for technicians from other areas of knowledge such as sociology and nutrition to be part of the agrarian extension technical team. On the other hand, the State should offer minimum conditions to keep them in its staff. Thus, the results suggest that the next strategic plans should strengthen the link of the extension with research including Higher Education Institutions. Because, it is the educational institutions that form extensionists and that should adjust their programs to the new paradigms of agrarian extension, to better guide extensionists in the search for solutions to farmers' problems. 
This study found that the low results attributed to agrarian extension services cannot be assigned only to extensionists. Therefore, there is a need to develop feasible and properly budgeted plans, allocate $1 \%$ of agrarian GDP, train technicians for the new paradigms of agrarian extension, allocate e circulating means to extensionists and adopt approaches that best suit farmers' reality and, on the other hand, the extension sector should focus on public-private partnerships with NGOs, research institutions, universities to enable more robust extensionist action.

Gêmo (2009) states that for the success of the extension and agrarian knowledge system depends heavily on the political will to promote agriculture; an institutional system oriented to the flow of knowledge (experimentation and implementation of innovation); an articulated demand between farmers and other actors and; effective availability of new knowledge and technologies linking the public system of research, local knowledge and external sources of knowledge.

\section{Acknowledgment}

We would like to express our heartfelt to the CAPES for the sponsorship for the first author for postgraduate program (PEC-PG) public notice2018, process $n^{\circ} 88881.284148 / 2018-01$

\section{References}

Adenle, A. A., Wedig, K., \& Azadi, H., (2019). Technology in Society Sustainable agriculture and food security in Africa: The role of innovative technologies and international organizations. 58, p.101. https://doi.org/10.1016/j.techsoc.2019.05.007

Aker, J. C. (2011). Dial "A" for agriculture: A review of information and communication technologies for agricultural extension in developing countries. Agricultural Economics, 42(6), 631-647. https://doi.org/10.1111/j.1574-0862.2011.00545.x

Albuquerque, A., \& Hobbs, A. (2016). Challenges and Opportunities for Efficient Land Use in Mozambique: Taxes, Financing, and Infrastructure A CPI Report 2 A CPI Report Challenges and Opportunities for Efficient Land Use in Mozambique.

Alves, E. R. A., Santana, C. A. M., \& Contini, E. (2016). Extensão Rural: Seu problema não é a comunicação. Agricultura, transformação produtiva e sustentabilidade, p. 391.

Anderson, J. R., \& Feder, G. (2003). Rural extension services. Agriculture and Rural Development Department. 3(September 2002), 30-31. https://doi.org/10.1596/1813-9450-2976

Asfaw, S., Shiferaw B., Sintowe F., \& Lipper L. (2012). Impact of modern agricultural technologies on smallholder welfare: Evidence from Tanzania and Ethiopia. Food Policy, v. 37(3), 283-295. https://doi.org/10.1016/j.foodpol.2012.02.013

Baloch, M. A., \& Thapa, G. B. (2019). Review of the agricultural extension modes and services with the focus to Balochistan, Pakistan. Journal of the Saudi Society of Agricultural Sciences, 18(2), 188-194. https://doi.org/10.1016/j.jssas.2017.05.001

Ban, V. A.W., \& Hawkins H. S. (1996). Extensão Rural. Second edition. 
Cadena-Iñiguez, P., Guevara-Hernandez, F., Arguello-Aguilar, R. A., \& Rendón-Medel, R. (2018). Proceso de comunicación, extensionismo y adopción de tecnologías Resumen Introducción. p. 851-864. https://doi.org/10.29312/remexca.v9i4.1401

Caporal, F. R. (2005). Política Nacional de Ater: primeiros passos de sua implementação e alguns obstáculos e desafios a serem enfrentados. Assistência técnica e extensão rural: construindo o conhecimento agroecológico. Manaus: Bagaço, p. 9-34.

Carrilho, J., Benfica, R., David. T., \& Boughton, D. (2003). Ministério Da Agricultura E Desenvolvimento Rural. Qual o Papel da Agricultura Familiar Comercial no Desenvolvimento Rural e Reduço da Pobreza em Moçambique? n. 53.

Castelo R. D., \& Braun, P. M. (2006). Framework On Effective rural Communication For Development Effective Rural Communication. p. 74.

Come, S., \& Cavane, E. (2014). A extensão rural pública: percepções dos produ- tores das associações agrícolas de Manhiça Sede, Moçambique. p. 127-153.

Cunguara, B., \& Darnhofer, I. (2011). Assessing the impact of improved agricultural technologies on household income in rural Mozambique. Food Policy, 36(3), 378-390. https://doi.org/10.1016/j.foodpol.2011.03.002

Cunguara, B., \& Moder, K. (2011). Is agricultural extension helping the poor? Evidence from rural Mozambique. Journal of African Economies, 20(4), 562-595. https://doi.org/10.1093/jae/ejr015

Cunguara, B., \& Thompson T. (2018). Mozambique: Desk Study of Extension and Advisory Services. Developing Local Extension Capacity (DLEC) Project.

Cunguara, B., Garrett, J., \& Donovan, C. (2013). Análise situacional , constrangimentos e oportunidades para o crescimento agrário em Moçambique.

Davis, K. E. (2008). Extension in sub-saharan Africa: Overview and assessment of past and current models, and future prospects. Journal of International Agricultural and Extension Education, 15(3), 15-28.

Davis, K., Ephraim, N., Kato, E., Mekonnem, D. A., Odendo, M., Miiro, R., \& Nkuba, J. (2010). Empowerment of Women Through Dairy Training, 20(1), 1-56.

DNEA. (2019). Relatorio Técnico. Ministério de Agricultura e Segurança Alimentar. p. 13.

Dzeco C., Amilai C., \& Cristóväo A. (2010). Farm field schools and farmer's empowerment in Mozambique: A pilot study. Journal of Extension Systems, 26(2), 116-124.

Fang, D., \& Richards, T. J. (2018). New Maize Variety Adoption in Mozambique: A Spatial Approach. Canadian Journal of Agricultural Economics, 66(3), 469-488. https://doi.org/10.1111/cjag.12166

Freire, P. (1983). Comunicação ou Extensão, 24.

Gêmo, H. (2009). Extensão Rural em Moçambique: Evolução, desafios e perspectivas (1975-2006): in Politicas Publicas e Desenvolvimento Rural: Percepcoes e Prespectivas no 
Brasil e em Mocambique. p. 267.

Gêmo, H. R., \& Davis, K. E. (2015). Addressing Human Capital Development in Public Agriculture Extension in Southern Africa: Assessing Mozambique's Experience. n. September, p. 1-25.

Gêmo, H. R., Stevens, J. B., \& Chilonda, P. (2013).The role of a pluralistic extension system in enhancing agriculture productivity in mozambique, 41, 59-75.

Gêmo, H., \& Rivera, W. M. (2001). Mozambique's move towards a pluralistic national system of rural extension. Network Paper - Agricultural Research and Extension Network; 110, 6 pp. 10 ref., n. 110.

Gêmo, H., Eicher, C. K., \& Teclemarian, S. (2005). Mozambican Experience in Building a National Extension System. Michigan State University. 31, 1-22.

Guanziroli, C. E. G. T. (2015). Modernização da Agricultura em Moçambique : determinantes da renda agrícola. 2015. https://doi.org/10.1590/1234-56781806-94790053s01009

Gulati A., Sharma B., Samantara A., \& Terway P. (2018). Agriculture Extension System in India. Review of current status, trends and the way forwad.

INE., (2019). Resultados Definitivos Instituto Nacional De Estatistica. Censo 2017. p. 95 ,

Innocent, M., \& Vasanthakaalam, H. (2018). Success story of implementing the self-sustaining agricultural extension system in Rwanda. 10(September), 175-185. https://doi.org/10.5897/JAERD2018.0981

Kelsey, B. (2013). Market inefficiencies and the adoption of agricultural technologies in developing countries. Ensemble, 15(4), 250-260.

Knickel, K., Redman, M., Danhofer, M., Ashkenaz, A., Chebach, C. T., Sumane, S., ... Rogge, E. (2018). Between aspirations and reality: Making farming, food systems and rural areas more resilient, Sustainable and Equitable, 59. https://doi.org/10.1016/j.jrurstud.2017.04.012

Kondylis, F., \& Mueller, V. (2014). Lessons from an agricultural extension experiment in Mozambique: insights on teaching modalities and gender representation in extension and on productivity measurement. n. October, p. 4.

Mabiso, A., Cunguara, B., \& Benfica, R. (2014). Food ( In ) security and its drivers : insights from trends and opportunities in rural Mozambique. p. 649-670. https://doi.org/10.1007/s12571-014-0381-1

MASA. (2014). Ministério da Agricultura e Segurança Alimentar Anuário de Estatísticas Agrárias Ministério da Agricultura e Segurança Alimentar Anuário de Estatísticas Agrárias 2012-2014.

MASA., (2015). Anuário de Estatísticas Agrárias 2015. p. 66.

MINAG., (2007). PLANO DIRECTOR DE EXTENSÃO AGRARIA 2007-2016.

MINAG., (2011). Plano Estratégico Para o Desenvolvimento do Sector Agrário - PEDSA 
2010-2020. p. 76.

Monteiro, L. M. (2017). Modelo “Top Down”: Uma Reflexão Sobre a Implementação De Políticas Públicas E a Participação Dos Gestores Governamentais. Revista Gestão Organizacional, 9(3), 25-35.

Mosca, J. (2017). Agricultura Familiar Em Moçambique: ideologias e políticas/ Family agriculture in Mozambique: ideologies and policies/ Agricultura familiar en Mozambique: ideologías y políticas. Revista Nera, O(38), 68-105.

Mubai, B. A. (2014). Os Serviços De Extensão Agrária Pública Ao Pequeno Agricultor Familiar Do Distrito De Boane-Moçambique. p. 1-28.

Muniz, J. N, Nhancale I.T., Soub J. C. R., \& Sala O. T. M., (2018). Planos e Programas e os Serviços de Extensão Rural em Moçambique: Solução ao hiato existente entre os eixos orientadores e a prestação dos serviços públicosPlans and programs and rural extension services in Mozambique: Solution to the existing gap between. Cadernos de Estudos Africanos, 35, 171-191. https://doi.org/10.4000/cea.2853

Mutimba, J. K. (2014). Reflections On Agricultural Extension And Extension Policy In Africa. 2014(June), 1-2.

Nuvunga, B. (2006). Reforma Agrária e Desenvolvimento Rural em Moçambique-Situação actual e Perspectivas. Documento apresentado na Conferência da FAO sobre a Reforma Agrária e Desenvolvimento Rural, Porto Alegre, Brasil, p. 1-22.

Sitoe, T. A. A. (2010). Extensão Agrícola e as "Escolas na Machamba do Camponês" em Moçambique: O Caso da Produção Hortícola nas Zonas Verdes da Cidade de Maputo. Revista $\begin{array}{lll}\text { Brasileira } & \text { Multidisciplinar, } & \text { 13(2), }\end{array}$ https://doi.org/10.25061/2527-2675/ReBraM/2010.v13i2.140

Szonyi, J., \& Blum, M. L. (2018). Evolution of country-specific investment requirements of agricultural and rural extension and advisory services.

Veraszto, E. V., Silva D., Miranda, N. A., \& Simon F. O. (2009). Tecnologia : buscando uma definição para o conceito Technology: looping for a definition for the concept Resumo Abstract. p. 19-46.

World Bank. (2006). Mozambique: Agricultural Development Strategy. Stimulating Smallholder Agricultural Growth. Social Development, n. Report number 32416-MZ, p. 143.

\section{Copyright Disclaimer}

Copyright for this article is retained by the author(s), with first publication rights granted to the journal.

This is an open-access article distributed under the terms and conditions of the Creative Commons Attribution license (http://creativecommons.org/licenses/by/4.0/). 